\title{
Hubungan Pembelajaran Jarak Jauh dan Gangguan Somatoform dengan Tingkat Stres Mahasiswa UIN Syarif Hidayatullah Jakarta
}

\section{The Relationship of Distance Learning and Somatoform Disorders with Stress Levels of UIN Syarif Hidayatullah Jakarta Students}

Rizky Muharany Putri, ${ }^{1}$ Anissa Dwi Oktaviani, ${ }^{1}$ Adi Setya Frida Utami, ${ }^{1}$ Ni maturrohmah, ${ }^{1}$ Halwa Ainaya Addiina, ${ }^{1}$ Hoirun Nisa, ${ }^{1 *}$

${ }^{1}$ Program Studi Kesehatan Masyarakat, Fakultas Ilmu Kesehatan, Universitas Islam Negeri Syarif Hidayatullah Jakarta, Tangerang Selatan 15419.

Korespondensi penulis:

hoirun.nisa@uinjkt.ac.id

\begin{tabular}{ll}
\hline Diterima (Recieved) & $: 25$ Juni 2020 \\
Direvisi (Revised) & $: 29$ Juni 2020 \\
Diterima untuk diterbitkan (Accepted) & $: 30$ Juni 2020
\end{tabular}

\begin{abstract}
ABSTRAK
Latar belakang. Physical distancing untuk mencegah penularan COVID-19 pada awal pandemi COVID-19 menyebabkan diterapkannya Pembelajaran Jarak Jauh (PJJ) di insititusi pendidikan, termasuk UIN Syarif Hidayatullah Jakarta.

Tujuan. Penelitian dilaksanakan untuk mengetahui hubungan PJJ dan gejala gangguan somatoform terhadap tingkat stres pada mahasiswa UIN Syarif Hidayatullah Jakarta pada masa awal pandemi COVID-19.

Metode. Penelitian ini adalah observasional analitik dengan pendekatan kuantitatif, desain studi cross sectional. Responden adalah 470 mahasiswa aktif Strata 1 UIN Syarif Hidayatullah Jakarta. Data diperoleh dengan penyebaran kuesioner secara online pada bulan April hingga Mei 2020. Analisis multivariat dilakukan dengan menggunakan uji regresi logistik ganda.

Hasil. Frekuensi pelaksanaan PJJ memiliki hubungan signifikan dengan tingkat stres responden. Hasil analisis multivariat menunjukkan bahwa mahasiswa yang telah melaksanakan PJJ $\geq 12$ kali cenderung memiliki stres tingkat rendah dibandingkan dengan mahasiswa dengan frekuensi $\mathrm{PJJ}<12$ (nilai $\mathrm{p}=0,039$ ). Gejala gangguan somatoform tidak memiliki pengaruh signifikan terhadap tingkat stres mahasiswa dalam melaksanakan PJJ (nilai $\mathrm{p}=0,228$ ).
\end{abstract}

Kesimpulan. Mahasiswa yang lebih sering melakukan PJJ cenderung memiliki tingkat stres yang lebih rendah.

Kata Kunci: pembelajaran jarak jauh, gangguan somatoform, tingkat stres.

\section{ABSTRACT}

Background. Physical distancing to prevent transmission of COVID-19 at the beginning of the COVID-19 pandemic has led to the implementation of distance learning (PJJ) in educational institutions, including UIN Syarif Hidayatullah Jakarta

Objective. The purpose of this study was to examine the relationship of distance learning and symptoms of somatoform disorders with stress levels of UIN Syarif Hidayatullah Jakarta students in the early COVID-19 pandemic.

Method. This study used an analytic observational with a quantitative approach, cross sectional study design. Respondents were 470 active students of UIN Syarif Hidayatullah Jakarta. Data were obtained by distributing questionnaires via online in April to May 2020. Multivariate analysis was performed using a multiple logistic regression test.

Results. The frequency of PJJ had a significant relationship with respondents' stress levels. The results of multivariate analysis showed that university students who had PJJ $\geq 12$ times were more likely to have low levels of stress compared to students with PJJ frequency of $<12$ (p-value=0.039). Symptoms of somatoform disorders did not have a significant effect on the level of stress of university students ( $p$-value $=0.228$ ).

Conclusion. University students who had done PJJ more often were likely to have lower stress levels.

Keywords: distance learning, somatoform disorders, stress level 


\section{LATAR BELAKANG}

Pada akhir tahun 2019, dunia dikejutkan dengan munculnya virus baru, yakni SARSCoV-2 yang menyebabkan COVID-19, yaitu penyakit pernapasan akut dengan masa inkubasi singkat dan juga memiliki penularan yang cepat. ${ }^{1}$ Berbagai upaya dilakukan untuk mencegah dan menekan angka kesakitan serta kematian yang disebabkan COVID-19. Di Indonesia, pemerintah menetapkan kebijakan pembatasan sosial berskala besar (PSBB) dan juga anjuran untuk melakukan physical distancing, yaitu memberi jarak dengan orang lain minimal satu meter selama kurang dari 15 menit untuk melindungi diri dari penyakit COVID-19 yang ditularkan melalui droplet. ${ }^{2}$

Anjuran penerapan physical distancing dan PSBB pun menimbulkan beberapa dampak, seperti ditutupnya berbagai fasilitas umum. Hal ini membuat pekerja harus menerapkan work from home ( $w f h$ ) dan pelajar/mahasiswa mengikuti kegiatan belajar mengajar jarak jauh (PJJ) dengan metode e-learning. Perubahan yang terjadi secara tiba-tiba ini, dapat berdampak pada kesehatan pekerja, pelajar dan mahasiswa, baik secara fisik maupun mental. Dampak kesehatan yang dapat terjadi karena ada perubahan metode pembelajaran langsung menjadi PJJ adalah stres. Kondisi ketika seseorang merasa begitu tertekan yang mungkin terjadi akibat beban kerja berat atau berlebihan. ${ }^{3}$

World Health Organization (WHO) pada tahun 2019 menyebutkan bahwa hampir 264 juta penduduk dunia mengalami stres dan/atau depresi. Kemudian, di Indonesia terdapat 6,1\% penduduk berusia $>15$ tahun yang mengalami depresi. ${ }^{4}$ Sekitar 10 juta penduduk Indonesia berusia $>15$ tahun yang mengalami depresi.

Berdasarkan penelitian yang dilakukan oleh Yikealo ${ }^{5}$, diketahui bahwa sebagian besar mahasiswa di Eritrea Institute of Technology cenderung mengalami stres tingkat sedang (71\%). Hasil penelitian tersebut menyebutkan bahwa stresor yang paling sering menjadi pemicu terjadinya stres pada mahasiswa yaitu fasilitas pembelajaran yang kurang memadai $(40,7 \%)$, kesulitan belajar untuk jangka waktu yang lama (32,5\%), tugas yang terlalu banyak, dan beban akademik $(23,5 \%)$. Penelitian ini juga menunjukkan bahwa mahasiswa tidak hanya mengalami stres, akan tetapi kondisi stres mental juga menyebabkan stres secara fisik pada mahasiswa. Penelitian tersebut menyebutkan bahwa ada 10 gejala atau gangguan kesehatan, antara lain kelelahan $(24,4 \%)$, nafsu makan menurun $(10,6 \%)$, back pain dan masalah pencernaan $(9,8 \%)$, demam $(7,3 \%)$, insomnia $(5,8 \%)$, sistem urinaria $(4,9 \%)$, sakit kepala dan denyut jantung meningkat $(4,1 \%)$, dan masalah sistem pernapasan $(3,3 \%){ }^{5}$

Berdasarkan penelitian sebelumnya, dapat diketahui bahwa stres, baik secara mental dan fisik, banyak terjadi pada masyarakat usia produktif, termasuk mahasiswa. Kemudian, dapat diketahui juga bahwa faktor-faktor akademik, seperti fasilitas pembelajaran yang kurang memadai, kesulitan dalam belajar untuk jangka waktu lama, terlalu banyak tugas dan beban akademik, dapat menyebabkan stres pada mahasiswa. Tujuan penelitian ini dilakukan untuk mengetahui hubungan antara penerapan PJJ metode e-learning dengan tingkat stres pada mahasiswa UIN Syarif Hidayatullah Jakarta pada masa awal pandemi COVID-19.

\section{METODE}

Desain penelitian cross-sectional dengan pendekatan kuantitatif dilakukan pada AprilMei 2020. Partisipan pada penelitian ini yaitu mahasiswa aktif strata-1 di UIN Syarif Hidayatullah Jakarta.

Besar sampel menggunakan perhitungan slovin dan ditambah $10 \%$, sehingga diperoleh 470 mahasiswa. Pengambilan sampel dengan menggunakan purposive sampling. Kriteria insklusi yaitu merupakan mahasiswa aktif jenjang sarjana UIN Syarif Hidayatulah Jakarta, melakukan PJJ atau sistem e-learning (dalam jaringan) dan bersedia menjadi responden. Pada penelitian ini, diperoleh sampel sebanyak 470 responden.

Data dikumpulkan secara online melalui google form. Adapun kuesioner google form berisi informasi terkait gejala somatoform, pelaksanaan PJJ, pendapat mahasiswa atas keefektifan pembejaran jarak jauh, metode interaksi yang digunakan saat PJJ dan perangkat elektronik yang digunakan saat PJJ. Kuesioner sudah diuji validitas dan reabilitasnya. Tingkat 
Putri et al. Perilaku dan Promosi Kesehatan: Indonesian Journal of Health Promotion and Behavior. 2020; 2(1): 38-45 DOI: $10.47034 /$ ppk.v2i1.4003

stres diukur menggunakan kuesioner yang diadaptasi dari Depression Anxiety Stress Scale (DASS) dari Psychology Foundation of Australia tahun 2018. Informed consent diberikan responden sebelum pengisian kuesioner secara online. Penelitian ini telah menerima kaji etik penelitian dari Fakultas Ilmu Kesehatan UIN Syarif Hidayatullah Jakarta dengan nomor Un.01/F.10/KP.01.1/KE.SP/ 04.08.011/2020.

Variabel independen dalam penelitian ini adalah pelaksanaan PJJ, pendapat mahasiswa mengenai keefektifan pembejaran jarak jauh, metode interaksi yang digunakan saat PJJ, perangkat elektronik yang digunakan pada saat PJJ dan gejala gangguan somatoform. Variabel dependennya adalah tingkat stres. Tingkat stres dikategorikan menjadi normal, ringan, sedang, dan berat. Seseorang dikatakan normal jika hasil skor <15, stres ringan jika hasil skor 15-18, stres sedang jika hasil skor 19-25 dan stres berat jika hasil skor $>26$. Untuk analisis, kelompok normal dan ringan menjadi satu kategori yaitu tingkat stres ringan, dan kelompok sedang dan berat menjadi satu kategori yaitu tingkat stres tinggi.

Variabel pelaksanaan PJJ dikategorikan menjadi $\geq 12$ kali dan $<12$ kali dalam 3 minggu terakhir. Frekuensi PJJ dihitung mulai dari UIN Syarif Hidayatullah Jakarta menetapkan tangal 16 Maret 2020 sebagai pelaksanaan PJJ hingga saat partisipan menjawab kuesioner penelitian. Keefektifan PJJ dikategorikan berdasarkan jawaban terbuka dari partisipan. Metode interaksi PJJ dikategorikan menjadi video call, chatting dan keduanya. Dikatakan metode interaksi video call jika media pembelajaran video seperti google meet, zoom digunakan. Metode interaksi chatting jika menggunakan media pembelajaran berbasis chatting seperti whatsapp, google class, edmodo, telegram dan Academic Information System (AIS), dan jika partisipan menjawab kedua metode interaksi video dan chatting maka dikategorikan menggunakan keduanya.

Variabel perangkat elektonik dikategorikan menjadi laptop, handphone, dan keduanya (laptop dan handphone). Gejala gangguan somatoform dikategorikan menjadi "iya" dan "tidak". Seseorang dikatakan iya memiliki gejala gangguan somatoform jika partisipan sering dan sering sekali mengalami gejalagejala gangguan somatoform seperti sakit pada bagian pinggang, pegal di bagian bahu, sakit kepala, mual, batuk, demam, sesak nafas, sakit tenggorokan, sakit dada, nafsu makan hilang, tidur tidak nyenyak, cemas, tegang, khawatir, sedih dan lain-lain. Dikatakan tidak memiliki gejala somatoform jika partisipan tidak pernah atau jarang mengalami gejala-gejala gangguan somatoform.

Data diolah menggunakan aplikasi IBM SPSS Statistic Version 22. Pengumpulan data dilakukan pada bulan April hingga Mei 2020. Analisis univariat digunakan untuk melihat distribusi frekuensi usia, jenis kelamin, bidang pendidikan, pelaksanaan PJJ, pendapat mahasiswa terhadap keefektifan PJJ, metode interaksi PJJ, perangkat elektronik, dan gejala gangguan somatoform. Analisis bivariat pada penelitian ini menggunakan uji chi-square. Selanjutnya analisis multivariat menggunakan uji regresi logistik ganda.

\section{HASIL}

Tabel 1 menyajikan distribusi frekuensi karakteristik responden. Pada penelitian ini, ditemukan bahwa dari 470 responden, rerata usia responden adalah 19 tahun, sebagian besar responden berjenis kelamin perempuan yaitu 377 responden, dan mahasiswa kesehatan yaitu 250 responden.

Analisis bivariat memperlihatkan bahwa, pelaksanaan PJJ berhubungan dengan tingkat stres. Dari 470 responden, ada 208 responden yang melaksanakan PJJ <12 kali dan 188 responden mengalami stres tinggi. Selain itu, 262 responden yang melaksanakan PJJ $\geq 12$ kali dan mengalami stres tinggi sebanyak 250 responden. Dari analisis bivariat diketahui bahwa variabel gejala gangguan somatoform berhubungan dengan tingkat stres. Dari 470 responden terdapat 168 responden yang memiliki gejala gangguan somatoform, dan 153 responden mengalami stres tinggi. Selain itu, terdapat 302 responden yang tidak memiliki gejala gangguan somatoform, dan mengalami stres tinggi sebanyak 285 responden. 
Tabel 1. Distribusi Responden Berdasarkan Karakteristik

\begin{tabular}{|c|c|c|c|c|}
\hline \multirow{2}{*}{ Variabel } & \multirow{2}{*}{$\mathbf{n}$} & \multicolumn{2}{|c|}{ Tingkat Stres } & \multirow{2}{*}{$p$-value } \\
\hline & & Tinggi & Rendah & \\
\hline Usia (tahun) & $\begin{array}{c}470 \\
(19,71 \pm 1,15)^{*}\end{array}$ & - & - & - \\
\hline \multicolumn{5}{|l|}{ Jenis Kelamin } \\
\hline Laki-laki & 93 & 84 & 9 & - \\
\hline Perempuan & 377 & 354 & 23 & \\
\hline \multicolumn{5}{|l|}{ Bidang Pendidikan } \\
\hline Mahasiswa Kesehatan & 250 & 234 & 16 & - \\
\hline Mahasiswa Non Kesehatan & 220 & 204 & 16 & \\
\hline \multicolumn{5}{|c|}{ Pelaksanaan Pembelajaran Jarak Jauh } \\
\hline$<12$ kali & 208 & 188 & 20 & $0,042 * *$ \\
\hline$\geq 12$ kali & 262 & 250 & 12 & \\
\hline \multicolumn{5}{|l|}{ Metode Interaksi PJJ } \\
\hline Video call & 31 & 29 & 2 & \\
\hline Chatting & 277 & 262 & 15 & 0,303 \\
\hline Video call dan chatting & 162 & 147 & 15 & \\
\hline \multicolumn{5}{|l|}{ Perangkat Elektronik } \\
\hline Laptop & 21 & 20 & 1 & \\
\hline Handphone & 55 & 51 & 4 & 0,924 \\
\hline Laptop dan Handphone & 394 & 367 & 27 & \\
\hline \multicolumn{5}{|l|}{ Gejala Gangguan Somatoform } \\
\hline Iya & 168 & 153 & 15 & $0,185^{* *}$ \\
\hline Tidak & 302 & 285 & 17 & \\
\hline
\end{tabular}

Keterangan: * Mean $\pm S D ; * *<0,25$ berlanjut ke analisis multivariat.

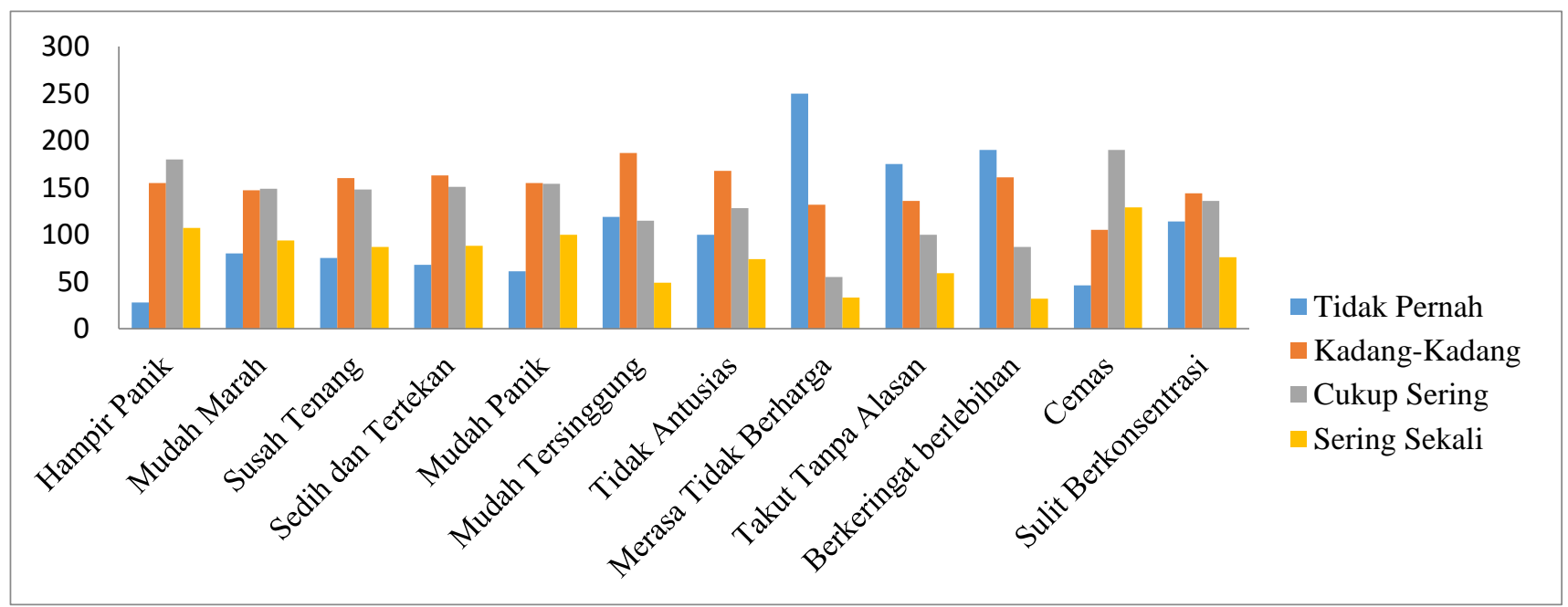

Gambar 1. Gambaran Variabel yang Menentukan Kategori Tingkat Stress Pembelajaran Jarak Jauh Pada Mahasiswa UIN Syarif Hidayatullah Jakarta

Gambar 1 memperlihatkan bahwa dari 470 responden, 180 responden menyatakan cukup sering panik, cukup sering mudah marah yaitu 149 responden, kadang-kadang susah tenang yaitu 160 responden, kadang-kadang sedih dan tertekan yaitu 163 res-ponden. Terdapat sebanyak 155 responden menyatakan kadang-kadang mudah panik, kadang-kadang mudah tersinggung yaitu 187 res-ponden, ka- dang-kadang tidak antusias yaitu 168 responden, tidak pernah merasa tidak berharga yaitu 250 responden. Sebanyak 175 responden tidak pernah takut tanpa alasan, tidak pernah berkeringat berlebihan saat PJJ berlangsung yaitu 190 responden, cukup sering merasakan cemas yaitu 190 responden, dan kadang-kadang sulit berkonsentrasi sebanyak 144 responden. 
Tabel 2 menunjukkan gambaran alasan ketidak-efektifan PJJ menurut mahasiswa UIN Syarif Hidayatullah Jakarta. Terdapat 427 responden menyatakan bahwa PJJ tidak efektif dan sebagian besar menyatakan alasannya karena gangguan sinyal dan jaringan yang sering tidak stabil.

Tabel 3 menyajikan hasil multivariat yang telah dikontrol dengan variabel karakteristik jenis kelamin, usia, dan bidang pendidikan. Hasil penelitian menunjukkan bahwa frekuensi pelaksanaan PJJ memiliki hubungan yang signifikan dengan tingkat stres responden (nilai $\mathrm{p}=0,039$ ). Responden dengan frekuensi PJJ sebanyak $\geq 12$ kali memiliki peluang 0,458 lebih kecil untuk stres tinggi dibandingkan dengan responden dengan PJJ sebanyak <12 kali (OR=0,458, 95\% CI: 0,218-0,963). Hasil analisis multivariat setelah dikontrol variabel karakteristik jenis kelamin, usia dan pendidikan, menunjukkan kesehatan fisik tidak ada hubungan yang signifikan dengan tingkat stres (nilai $\mathrm{p}=0,228$ ).

Tabel 2. Pendapat Mahasiswa Terhadap Keefektifan Pembelajaran Jarak Jauh

\begin{tabular}{lrr}
\multicolumn{1}{c}{ Alasan Keefektifan Pembelajaran Jarak Jauh } & n & \\
\hline & & 18,5 \\
Tugas terlalu banyak/ Deadline singkat & 79 & 41,0 \\
Terkendala Media & 17 & 20,4 \\
Sinyal dan Jaringan & 87 & 14,8 \\
Mahasiswa kurang memahami materi & 63 & 20,1 \\
Dosen kurang maksimal dalam menjelaskan/ Tidak menjelaskan & & 3,0 \\
sama sekali & 86 & 8,6 \\
Boros Kuota & 13 & 10,5 \\
Lainnya & 37 & 45 \\
Tidak ada alasan & 45 \\
\hline
\end{tabular}

Tabel 3. Distribusi Responden Berdasarkan Pelaksanaan Pembelajaran Jarak jauh dan Gejala Gangguan Somatoform Terhadap Tingkat Stres

\begin{tabular}{|c|c|c|c|c|}
\hline \multirow[b]{2}{*}{ Variabel } & \multicolumn{3}{|c|}{ Analisis Multivariat* } & \multirow[b]{2}{*}{$p$-value } \\
\hline & $\begin{array}{c}\text { Adjusted* } \\
\text { OR }\end{array}$ & SE & CI $95 \%$ & \\
\hline $\begin{array}{l}\text { Pelaksanaan Pembelajaran Jarah Jauh } \\
\quad<12 \text { kali } \\
\quad \geq 12 \text { kali }\end{array}$ & 0,458 & 0,380 & $0,218-0,963$ & 0,039 \\
\hline $\begin{array}{l}\text { Gejala Gangguan Somatoform } \\
\text { Iya } \\
\text { Tidak }\end{array}$ & 1,565 & 0,375 & $(0,755-3,242)$ & 0,228 \\
\hline
\end{tabular}

*Setelah dikontrol dengan jenis kelamin, bidang pendidikan, dan usia.

\section{PEMBAHASAN}

Hasil penelitian ini menunjukkan bahwa frekuensi pelaksanaan PJJ sejak diberlakukan sistem PJJ hingga Mei 2020 yaitu mayoritas mahasiswa telah mengikuti PJJ $\geq 12$ kali sebanyak 55,7\% dan <12 kali sebesar 44,3\%. Penelitian ini menunjukkan bahwa meskipun perkuliahan menggunakan metode PJJ dengan e-learning, namun dosen tetap konsisten dalam mengadakan perkuliahan dan mahasiswa tetap menghadiri perkuliahan.

Hasil penelitian ini menemukan bahwa sebagian besar mahasiswa tidak mengalami gejala gangguan somatoform, yakni sebesar $64,3 \%$, namun sebanyak $35,7 \%$ mahasiswa mengalami gangguan somatoform. Dalam hal ini menunjukkan selama 2 sampai 3 minggu sudah diberlakukannya pembelajaran jarak jauh, mahasiswa mampu menjaga kesehatan tubuhnya sehingga tidak mengalami gejala gangguan somatoform.

Pada hasil penelitian ini menjelaskan bahwa gejala gangguan somatoform memiliki hubungan signifikan terhadap tingkat stres pada mahasiwa (nilai $\mathrm{p}=0,185$ ). Selain itu, frekuensi pelaksanaan PJJ juga memiliki hubungan bermakna dengan tingkat stres pada mahasiswa (nilai $\mathrm{p}=0,042$ ). Hal ini sejalan dengan penelitian yang dilakukan Zulkifli ${ }^{6}$ mengenai masa kerja dengan stres kerja pada karyawan yang telah bekerja selama $<3$ tahun dan $>3$ tahun. Dalam penelitian menunjukkan 
Putri et al. Perilaku dan Promosi Kesehatan: Indonesian Journal of Health Promotion and Behavior. 2020; 2(1): 38-45 DOI: $10.47034 /$ ppk.v2i1.4003

bahwa pekerja dengan masa kerja lebih lama akan cenderung mempunyai kemampuan dan pemahaman yang lebih baik mengenai pekerjaannya dan pekerja dengan masa kerja yang lebih pendek mempunyai kemungkinan lebih besar untuk mengalami stres kerja (nilai $\mathrm{p}=0,017)$.

Temuan pada penelitian ini, tidak terdapat hubungan antara metode interaksi PJJ dan perangkat elektronik dengan tingkat stres. Pakarbudi $^{7}$ menjelaskan bahwa technostress merupakan salah satu bentuk stres kerja yang terjadi karena adanya kombinasi antara kemajuan teknologi informasi, ada tuntutan waktu, ketidak-cukupan pengetahuan, dan hasil dari tekanan psikologis. Technostress disebabkan karena penggunaan teknologi secara terusmenerus. Dalam hal ini mahasiswa dianggap sudah terbiasa menggunakan perangkat elektronik seperti laptop dan handphone untuk kebutuhan selama masa perkuliahan sebelum ada sistem PJJ. Hasil penelitian sebelumnya melaporkan laptop dan handphone sering digunakan pada mahasiswa. ${ }^{8}$

Ada hubungan yang signifikan antara frekuensi pelaksanaan PJJ dengan tingkat stres mahasiswa yakni dengan nilai $\mathrm{p}=0,039$. Stres terjadi ketika ada stressor. Pada penelitian ini mahasiswa dihadapkan pada suatu perubahan kebiasaan dalam kurun waktu yang relatif singkat yaitu dari yang biasanya kuliah secara tatap langsung dengan datang ke kampus menjadi kuliah melalui metode e-learning. ${ }^{9}$ Saat situasi seperti ini memang perlu adanya adaptasi lingkungan dari suatu perubahan tersebut. Penelitian Fuad ${ }^{10}$ menemukan bahwa perubahan situasi yang tidak diinginkan pada seseorang dapat menimbulkan stres psikologis. Hal ini karena aktivitas yang biasa dilakukan sehari-hari cenderung membentuk suatu pola tertentu sehingga meminimalkan jumlah energi dan sumber daya yang dikeluarkan. Ketika kebiasaan itu berubah, situasi yang muncul menekan seseorang menggunakan energi yang lebih besar untuk dapat beradaptasi. Penelitian Hanafi ${ }^{11}$ menunjukkan bahwa mahasiswa yang sedang mengerjakan skripsi juga mengalami perubahan kegagalan strategis yang bisa menjadi faktor risiko dari kejadian gangguan somatoform dalam proses memelihara self-regulated learning.
Penelitian ini juga menunjukan bahwa frekuensi mahasiswa dalam mengikuti pelaksanaan PJJ sebanyak $\geq 12$ kali cenderung menurunkan risiko sebesar 0,458 kali untuk mengalami stres tinggi dibandingkan dengan mahasiswa yang mengikuti pelaksanaan PJJ sebanyak < 12 kali. Hal ini mungkin terjadi karena mahasiswa yang sudah lebih banyak mengikuti PJJ telah mampu beradaptasi dan mampu mengelola tingkat stres dengan lebih baik dibandingkan dengan mahasiswa yang baru melaksanakan PJJ. Penelitian ini sejalan dengan hasil penelitian Asmarani ${ }^{12}$ yang menunjukkan hubungan yang signifikan antara kemampuan adaptasi terhadap kebisingan di tempat kerja dengan stres kerja karyawan. Hal ini menunjukkan bahwa kemampuan adaptasi yang baik terhadap kebisingan maka stres kerja menjadi rendah, dan jika kemampuan adaptasi kurang baik terhadap kebisingan maka stres kerja cenderung tinggi.

Hubungan gejala gangguan somatoform dengan tingkat stres mahasiswa menunjukkan bahwa ada hubungan yang tidak signifikan antara gejala gangguan somatoform dengan tingkat stres pada mahasiswa yakni nilai $\mathrm{p}=0,225$. Meskipun tidak terdapat hubungan yang signifikan, nilai OR menunjukkan bahwa mahasiswa yang mengalami gejala gangguan somatoform cenderung meningkatkan risiko untuk mengalami stres tinggi sebesar 1,565 kali daripada mereka yang tidak mengalami gejala.

Nathania ${ }^{13}$ menyatakan bahwa stres dapat menyebabkan perubahan fisiologis sebagai respon tubuh terhadap stressor. Ketika stressor mengaktifkan sistem saraf simpatis dan adrenokortikal, hal ini mempengaruhi homeostasis dan interaksi dengan lingkungan dan berperan terhadap fungsi katabolik. Perubahan ini dapat mempengaruhi keadaan fisiologis seseorang, seperti imunitas yang menurun dan gangguan kardiovaskular.

Penelitian Akbar ${ }^{14}$ menemukan kebugaran fisik dapat mempengaruhi seseorang dalam pengelolaan stres individu, dimana individu yang rajin berolahraga akan merangsang pertumbuhan dan perkembangan jasmani, rohani, dan sosial yang terkait struktur anatomis dan fisiologis, emosional, kecerdasan intelektual, dan kemampuan sosialisasi di lingkungannya. Hal ini dapat memunculkan perasaan senang 
yang dapat meningkatkan aspek sehat secara psikologis. Pembelajaran kuliah dengan sistem e-learning dalam waktu yang lama akan membuat mahasiswa lebih lama dalam keadaan statis. Kondisi ini dapat membuat mahasiswa menjadi kurang memiliki ruang gerak dalam melakukan olahraga sehingga cenderung akan meningkatkan risiko mengalami stres.

Penelitian Yunitasari ${ }^{15}$ melaporkan bahwa terdapat hubungan signifikan gejala gangguan somatoform dengan tingkat stres pada lansia dengan nilai $p=0,03$. Hal ini dapat dipengaruhi oleh faktor-faktor seperti kebiasaan rutin melakukan pemeriksaan kesehatan tubuh, konsumsi makanan bergizi, olahraga, dan istirahat yang cukup.

Keterbatasan penelitian adalah peran faktor lain yang dapat menyebabkan seseorang mengalami gangguan somatoform sehingga meningkatkan risiko stres, namun tidak diteliti.

\section{KESIMPULAN}

Gejala gangguan somatoform tidak berhubungan dengan tingkat stres mahasiswa pada masa-masa awal pandemi COVID-19. Mahasiswa yang lebih sering mengikuti PJJ akan mampu berdaptasi dan mampu mengelola stres dengan lebih baik dibandingkan dengan mahasiswa yang baru mengikuti pelaksanaan PJJ.

\section{SARAN}

Mahasiswa yang lebih sering mengikuti PJJ cenderung untuk tidak mengalami stres. PJJ dipandang tidak efektif karena gangguan sinyal dan jaringan di masing-masing daerah yang sering tidak stabil. Perlu diperhatikan untuk meningkatkan fasilitas dan kualitas PJJ jika sistem PJJ masih harus diteruskan karena kondisi pandemi COVID-19.

\section{UCAPAN TERIMA KASIH}

Peneliti mengucapkan terima kasih pada semua responden yang berpartisipasi dalam penelitian ini.

\section{DAFTAR REFERENSI}

1. Zhou W. The Coronavirus Prevention Handbook 101 Science Based-Tips That Could Save Your Life. China: Guangzhou Medical University; 2020.
2. New Zealand Ministry of Health. COVID-19: Guidelines for Hospitality Establishment on Physical Distancing and Gathering Sixe Limits. New Zealand: Ministry of Health New Zealand; 2020.

3. Gaol, Lumban. Teori Stres : Stimulus, Respons, dan Transaksional. Buletin Psikologi [serial on the Internet]. June 2016 [cited 2020 June 5]; 24 (1), p. 1-11. Available from: https://jurnal.ugm.ac.id/buletinpsikologi/article/view/11224/pdf

4. Kemenkes RI. Hasil Utama Riskesdas 2018. Jakarta: Kemenkes RI; 2018.

5. Yikealo D, Tareke W, Karvinen I. The Level of Stress among College Students: A Case in the College of Education, Eritrea Institute of Technology. Open Source Journal [Internet]. 2018 [cited 2020 Jun 16]; Available from: https://www.researchgate.net/publication/329043569_The_Level_of_Stress_amon g_College_Students_A_Case_in_the_College_of_Education_Eritrea_Institute_of_Technology

6. Zulkifli, Z., Rahayu, S. T., \& Akbar, S. A. Hubungan Usia, Masa Kerja, dan Beban Kerja dengan Stres Kerja Pada Karyawan Service Well Company PT. ELNUSA TBK Wilayah Muara Badak. Kesmas Uwigama: Jurnal Kesehatan Masyarakat [serial on the Internet]. June 2019 [cited 2020 June 11]; 5 (1), p. 4661. Available from: https://journal.uwgm.ac.id/index.php/KESMAS/article/view/831/470

7. Pakarbudi, A. Analisis Dampak Technostress Pada Pengguna E-Learning dengan Menggunakan Structural Equation Modeling (SEM). [Skripsi]. Surabaya: Institut Teknologi Sepuluh Nopember; 2015.

8. Kominfo RI. Survey Penggunaan TIK: Serta Implikasinya terhadap Aspek Sosial Budaya Masyarakat. Jakarta: Pusat Penelitian dan Pengembangan Aplikasi Informatika dan Informasi dan Komunikasi Publik; 2017.

9. Gaol, Lumban. Teori Stres: Stimulus, Respons, dan Transaksional. Buletin Psikologi [serial on the Internet]. June 2016 [cited 2020 June 5]; 24 (1), p. 1-11. Available from: https://jurnal.ugm.ac.id/buletinpsikologi/article/view/11224/pdf

10. Fuad, Fitri Tasliatul. Hubungan antara Penyesuaian Diri di Perguruan Tinggi dan Stres Psikologis Pada Mahasiswa Tahun Pertama fakultas Psikologi Universitas Indonesia [Skripsi]. Jakarta: Universitas Indonesia; 2013.

11. Hanafi, S. P., Dewi, K. S., \& Setyawan, I. Hubungan Antara Self-Regulated Learning 
Putri et al. Perilaku dan Promosi Kesehatan: Indonesian Journal of Health Promotion and Behavior. 2020; 2(1): 38-45

DOI: $10.47034 /$ ppk.v2i1.4003

dengan Gejala Gangguan Somatisasi Pada Mahasiswa Skripsi Fakultas Psikologi Universitas Diponogoro Semarang. Undip EJournal [serial on the Internet]. March 2013 [cited 2020 June 13]; 2(3): p. 1-9. Available from:

https://www.google.com/url?sa=t\&source=w eb\&rct=j\&url=https://ejournal3.un-

dip.ac.id/index.php/empati/article/download/7375/7135\&ved=2ahUKEwi89vQ_JvqAhWOf30KHfTID1cQFjADegQIAhAB\&usg=AOvVaw2iiU33ZdxWLj4uSRl6uRe

12. Asmarani, R. Hubungan antara Kemampuan Adaptasi terhadap Kebisingan dengan Stres Kerja Karyawan. Jurnal Studia Insania [serial on the Internet]. May 2017 [cited 2020 June 12]; 5(1): p. 71-93. Available from: https://jurnal.uin-antasari.ac.id/index.php/insania/article/download/1356/1076

13. Nathania, A., Dinata, I.M.K., \& Griadhi, I P A. Hubungan Stres Terhadap Kelelahan Pada Mahasiswa Fakultas Kedokteran Universitas Udayana. Intisari Sains Medis [serial on the Internet]. April 2019 [cited 2020 June 12]; 10(1): p.134-138. Available from: https://isainsmedis.id/index.php/ism/article/viewFile/400/244

14. Akbar, M. S. Profil Gaya Hidup Sehat Mahasiswa Fakultas Pendidikan Olahraga dan Kesehatan (FPOK). [Skripsi]. Bandung: Universitas Pendidikan Indonesia; 2012.

15. Yunitasari. Faktor-Faktor yang Mempengaruhi Tingkat Stres Pada Lansia Pensiunan di Wilayah Kerja Puskesmas Pelitakan Kabupaten Polewali Mandar. [Skripsi]. Makassar: Universitas Hassanudin; 2011. 